\title{
DEVELOPMENT OF IN VITRO STERILIZATION PROTOCOL FOR DO-1 (Prunus domestica) ROOTSTOCK
}

\author{
UGUR, R. \\ East Mediterranean Transitional Zone Agricultural Research Institute, Hacimustafa Mah. Gazi \\ Mustafa Kemal Bulvari No: 122 (Adana Yolu Uzeri 5. Km) Onikisubat/Kahramanmaras, Turkey \\ (e-mail: remzibey@hotmail.com; phone:+90-536-925-9915, +90-344-237-6020; \\ fax: $+90-344-237-7196)$ \\ (Received $30^{\text {th }}$ Oct 2019; accepted $30^{\text {th }}$ Jan 2020)
}

\begin{abstract}
Commercial companies have focused on clonal rootstocks free of diseases and been propagated through tissue culture for fruit seedling production lately to obtain products with higher quality and quantity. Two important stages in tissue culture are surface sterilization and in vitro culturing of the explants to be micro-propagated. Because prunus varieties which sources of explants are grown on open lands, contamination risk is higher. This study has been conducted to minimize the contamination of DO1 (Prunus domestica) explants by microorganisms as prunus rootstock for micropropagation. Several concentrations and application durations of 4 different sterilization agents $\left(\mathrm{HgCl}_{2}, \mathrm{NaClO}, \mathrm{H} 2 \mathrm{O} 2\right.$, and $\left.\mathrm{AgNO} 3\right)$ have been applied on the axillary buds taken from the rootstock for surface sterilization. Then, the explants have been transferred to MS nutrient media and the number of the aseptic explants was determined. Shoot and leaf regeneration have been observed on the aseptic explants 40 days after the application. While the highest aseptic explant rate (91\%) was achieved with $2 \% \mathrm{NaClO}$ application in 15 minutes, the lowest aseptic explant rate $(23.33 \%)$ was achieved with $0.5 \% \mathrm{HgCl}_{2}$ application in ten days. Finally, the lowest contamination rate was observed in $\mathrm{NaClO}$ applications (18.34\%) and the highest contamination rate was observed in $\mathrm{HgCl}_{2}$ applications among the sterilization agents.
\end{abstract}

Keywords: in vitro, micropropagation, prunus, rootstock, sterilization

\section{Introduction}

Turkey is among the leading fruit producers in the world with 226.783 ha of plantation area and 2.138.393 tons of apricot, plum, peach-nectarine and almond production (FAO, 2019). These fruits are produced in different regions of the country with different climatic conditions. This situation affects the production stability of these fruit species. Therefore, the usage of suitable clonal rootstock compatible with the soil conditions of the region is very important. Recently, high quality genotypes which have been tolerant to diseases and pests, compatible with scion, adaptable to different climatic conditions, positive effect yield and fruit quality of fruit varieties have been selected as rootstock and propagated clonally in the modern horticulture (Beckman and Lung, 2003; Nimbolkar et al., 2016; Suranyi et al., 2019). Generally, clonal production through vegetative ways in rootstock improvement and rootstock production are made by cuttings and tissue culture. High numbers of plants having the same genetic structure can be produced in a quick way free of diseases and viruses during micropropagation using tissue culture. Propagation by cutting, one of classical production methods, is dependent on seasons, whereas production in vitro conditions is constantly possible in all season with proper explants and subcultural applications (Wolella, 2017). Micropropagation has become important quality criteria in terms of obtaining healthier and homogenous plants in improvement of Prunus rootstock breeding studies (Martinez-Gomez et al., 2005). Micropropagation techniques are commonly used in many Prunus species; apricot (Reighard et al., 1990; Perez-Tornero et al., 1999), almond (Ainsley et al., 2001; Choudhary et al., 2015), peach (Bhansali et al., 1990; Declerck and Karbon, 1996; Felek et al., 2015), cherry (Matt and Jehle, 2005; 
Ružić and Vujović, 2008; Zarei et al., 2013) and in certain Prunus hybrid rootstocks (Tsipouridis and Thomidis, 2003; Felipe, 2009; Dejampour et al., 2011; Canlı and Demir, 2014). Sterilization is important in vitro tissue culture such as tools, equipment and nutrient medium. And besides surface sterilization of the explants, seeds, bulbs, leaves, stems, shoots, etc. taken in vivo such as fields, greenhouses, gardens, etc. are important (Babaoğlu et al., 2002). Obtaining aseptic explant is the first stage of tissue culture. It is also for viability of the explants taken into in vitro culture following surface sterilization. Microbial contamination is a serious problem in micropropagation. It causes significant number of plant losses in micropropagation (Da Silva and Kulus, 2014). Minimization of the losses are crucial for sustainability of the study (Nazary and Aghaye, 2012). Especially fungus, bacteria, viruses and yeasts cause microorganism contaminations in vitro culture (Omamor et al., 2007; Altan et al., 2010; Da Silva et al., 2016; Hesami et al., 2018). They cause decaying such as white, yellow and pink colonies of the nutrient medium. Another factor is which fungi are transmitted by either explant source or from the air. They may also cover the nutrient media with their grey micelles. Many researchers suggested that the main damage of these microorganisms should be defined as their nutritional competition with the explant on the medium (Nazary and Aghaye, 2012; Da Silva et al., 2016). Many activities occur during this process; slow growth of explants, necrosis formed on tissues, reduction on tissue regeneration and rooting, and their results can be disruptions leading to explant death (Mihaljevic et al., 2013). For the solution of these problems, an appropriate surface sterilization method, which varies according to the plants among the species, should be determined. Even different concentrations of chemical agents, impacts of application times within the same varieties of a single species influence the success of the surface sterilization. There are some other factors that affect performance; such as season of taking the explant, density and type of the microorganisms on the same explants but in different places (Bhojwani and Razdan, 2005; Eed et al., 2010).

Various commercial bleaches including sodium hypochlorite $(\mathrm{NaClO})$, calcium hypochlorite $\left(\mathrm{Ca}(\mathrm{ClO})_{2}\right)$ and ethanol $\left(\mathrm{C}_{2} \mathrm{H}_{6} \mathrm{O}\right)$ are densely used for surface sterilization of the explants in vitro culture in many plant species. Besides, the chemical agents such as mercury chloride $\left(\mathrm{HgCl}_{2}\right)$, hydrogen peroxide $\left(\mathrm{H}_{2} \mathrm{O}_{2}\right)$ and silver nitrate $\left(\mathrm{AgNO}_{3}\right)$ are used as disinfectants (Andreu and Marin, 2005; Arab et al., 2014). In addition, some pretreatments are carried out according to contamination, size and type of plant material prior to sterilization with chemicals. If the explant is big in size, generally the plant material is first washed under the tap water and kept in alcohol for several seconds (1 to 30 seconds) for sterilization of the plant material, which is followed by the actual surface sterilization. In case of an explant with an indented surface, 2 to 4 drops of Tween 20 may be dripped into the sterilization solution in order to benefit from diffuser and adhesive characteristics of such substance for the purpose of increasing effectiveness of the surface sterilization solution. Despite the chemical agents used in surface sterilization during in vitro culture studies, the establishment of the right protocol specific to using the plant material is the most important step of a successful study (Papafotiu and Martini, 2009).

There are no universal sterilization agents and nutrient medium for in vitro culture because rootstocks are genetically specific with regard to different components of the medium. Whereas MS (Murashige and Skoog, 1962) has been proved to be most suitable medium for successful explant development of stone fruits (almond, apricot and peach). Thus, the objective of this study was to develop on effective sterilization protocol for in vitro clonal prunus rootstock DO-1 ( $P$. domestica). In this study, the axillary bud explants 
of DO-1 (P. domestica) clonal rootstock which was obtained through selection breeding program which was treated with different concentrations of four chemical agents $\left(\mathrm{HgCl}_{2}\right.$, $\mathrm{NaClO}, \mathrm{H}_{2} \mathrm{O}_{2}$ and $\mathrm{AgNO}_{3}$ ) in different time durations as well as the most favorable sterilization protocol were studied. As a result of the study, the surface sterilization protocol at the lowest contamination level and giving the least damage to the explants of DO-1 ( $P$. domestica) rootstock cultures in vitro was obtained.

\section{Materials and Methods}

This study was carried out at the Plant Tissue Culture Laboratory of Eastern Mediterranean Transitional Zone Agricultural Research Institute, Kahramanmaras / Turkey, on April and May 2018. The study material consisted of young and healthy shoots at a length of 20 to $25 \mathrm{~cm}$, which contained 10-15 buds on them, were grown in greenhouse and obtained from DO-1 ( $P$. domestica) rootstock improved by Eastern Mediterranean Transitional Zone Agricultural Research Institute. The shoots were taken from the mother plant and the leaves on the shoots were cut and brought to the preliminary preparation room of the laboratory in a container full of water before taking into in vitro culture. The factors that dust and waste of insects which negative effect on sterilization application exist on the shoots were cleaned out with sterile water. Then, such shoots were cut at a length of $2.5-3.5 \mathrm{~cm}$ in such a way to contain one bud on each of them and the obtained explants were brought into sterile cabin in order to perform surface sterilization procedures. The explants were kept in $70 \%$ alcohol for a duration of 30 seconds in the sterile cabin as a pretreatment procedure before application of the chemical agents to be used in surface sterilization. Later on, they were rinsed with distillate water for three times in order to avoid the caustic effect of the alcohol.

When ethanol application was completed, explants were kept in solutions, which were prepared at different concentrations of 4 different sterilization agents as shown in Table 1 for different periods. During this period, the bottle was shaken slightly in order to increase the effect of the solution on the explant surface. At the end of the awaiting duration, the sterilization solution at each application was poured down and the explants were rinsed for 3 times in sterile pure water (Figure 1).

Covered with roughing filter paper petri dishes were used for sterilization for a duration of 20 minutes at $121^{\circ} \mathrm{C}$ at the autoclave. When surface sterilization was completed, excess water of the explants was taken with these petri dishes. After taking the first water of the explants, they were transferred to another petri and the cap of the petri was left half open in order to let it lose the water drops and the humidity on the explants. In addition, each tools used for surface sterilization (bottles, petri dishes, forceps, bistouries and the bottles full of water) were exposed to sterilization at the autoclave at $121^{\circ} \mathrm{C}$ for a duration of 20 minutes. Before the autoclave process; the forceps and the bistouries were wrapped with aluminum folio and left in refrigerator bags, the caps of the bottles were strapped with autoclave band and the petri dishes were placed in autoclave bags. In addition, the forceps and the bistouries used in the sterile cabin were kept in the sterilizer in the cabin; and they were used during the study repeatedly through treatment with alcohol.

During all applications the damaged parts of the tissues as well as all the irregular and unnecessary parts were removed by the help of forceps and bistouries. The explants at the length of $2 \mathrm{~cm}$ and containing one bud on each of them were planted in the nutrient media 
in such a way to keep the leaf stalks at the upper part with an angle at an amount of $45^{\circ}$ to the nutrient media.

Table 1. Chemicals used in surface sterilization applications and their application durations

\begin{tabular}{|c|c|c|c|}
\hline \multirow[b]{2}{*}{ Treatments } & \multirow[b]{2}{*}{ Chemical agents } & \multicolumn{2}{|c|}{ Application Combinations } \\
\hline & & $\begin{array}{c}\text { Concentrations } \\
\left(\% \mathbf{w v}^{-1}\right)\end{array}$ & $\begin{array}{c}\text { Durations } \\
\text { (minute) }\end{array}$ \\
\hline $\mathrm{T} 1$ & $\mathrm{HgCl}_{2}$ (Mercuric (II) chloride) & 0.1 & 15 \\
\hline $\mathrm{T} 2$ & $\mathrm{HgCl}_{2}$ (Mercuric (II) chloride) & 0.5 & 10 \\
\hline $\mathrm{T} 3$ & $\mathrm{HgCl}_{2}$ (Mercuric (II) chloride) & 1.0 & 5 \\
\hline $\mathrm{T} 4$ & $\mathrm{NaClO}$ (Sodium hypochlorite) & 1.0 & 30 \\
\hline $\mathrm{T} 5$ & $\mathrm{NaClO}$ (Sodium hypochlorite) & 1.5 & 20 \\
\hline $\mathrm{T} 6$ & $\mathrm{NaClO}$ (Sodium hypochlorite) & 2.0 & 15 \\
\hline $\mathrm{T} 7$ & $\mathrm{H}_{2} \mathrm{O}_{2}$ (Hydrogen peroxide) & 20.0 & 30 \\
\hline $\mathrm{T} 8$ & $\mathrm{H}_{2} \mathrm{O}_{2}$ (Hydrogen peroxide) & 30.0 & 20 \\
\hline T9 & $\mathrm{H}_{2} \mathrm{O}_{2}$ (Hydrogen peroxide) & 40.0 & 10 \\
\hline T10 & $\mathrm{AgNO}_{3}($ Silver nitrate $)$ & 0.5 & 30 \\
\hline $\mathrm{T} 11$ & $\mathrm{AgNO}_{3}$ (Silver nitrate) & 1.0 & 20 \\
\hline $\mathrm{T} 12$ & $\mathrm{AgNO}_{3}$ (Silver nitrate) & 1.5 & 10 \\
\hline
\end{tabular}
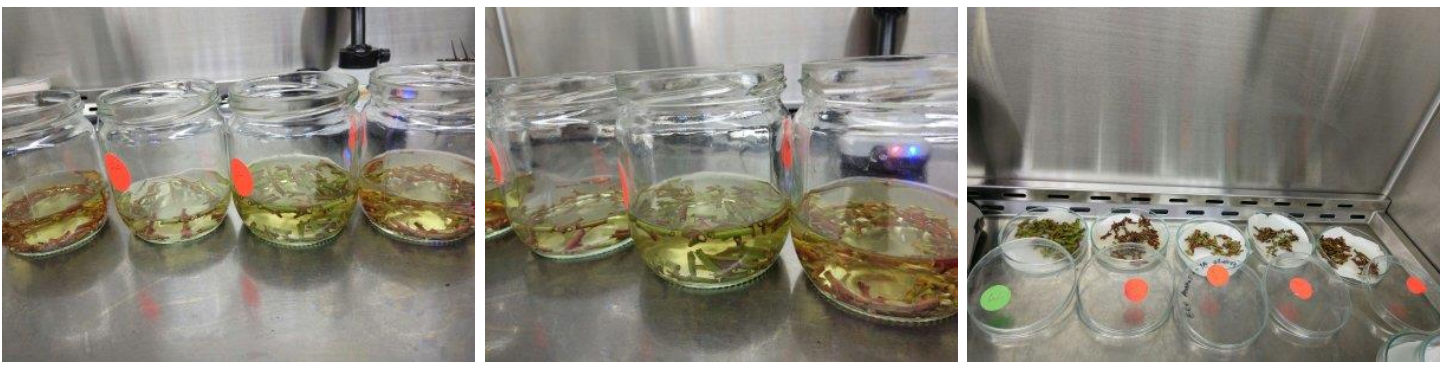

Figure 1. Stages of application with different chemical agents for surface sterilization to the explants

MS (Murashige and Skoog, 1962) nutrient media supplemented with $0.5 \mathrm{mg} / \mathrm{l} \mathrm{BAP}$ in combination with $0.1 \mathrm{mg} / \mathrm{l}$ of IBA was used for regeneration of the explants in vitro tissue culture. $\mathrm{pH}$ was adjusted to 5.6 to 5.8 with $1 \mathrm{~N} \mathrm{NaOH}$ or $1 \mathrm{~N} \mathrm{HCI}$ and then 30 g.L. ${ }^{-1}$ sucrose and 8 g.L $\mathrm{L}^{-1}$ agar were added into the MS medium. After addition and dissolution of agar, the nutrient media were sterilized at the autoclave at $121^{\circ} \mathrm{C}$ at 1.2 atmospheric pressure for a duration of 15 minutes. Clear glass bottles of $350 \mathrm{ml}$ containing MS medium of $65 \mathrm{ml}$ were used as culture containers. Each bottle was labeled with tags of different colors having different sterilization application information on them. All in vitro culture conditions were incubated at climate chamber at 16/8 light/dark photoperiod adjusted to $40 \mu \mathrm{mol} \mathrm{m} \mathrm{m}^{-2} \mathrm{~s}^{-1}$ light density, $25 \pm 2{ }^{\circ} \mathrm{C}$ temperature and $70-80 \%$ humidity (Figure 2).

In all different sterilization application, 15 bottles of $350 \mathrm{ml}$ were placed in the testing area randomly. Sterilization data were completed in 28 days, once in 7 days. The shoot and leaf growth data were taken after 40 days for the vivid explants and the effect of different sterilization methods were investigated for plant growth in vitro culture. The shoot growth was measured as the length of the shoots at the end of 28-days duration. Then such data were interpreted as percentage. 


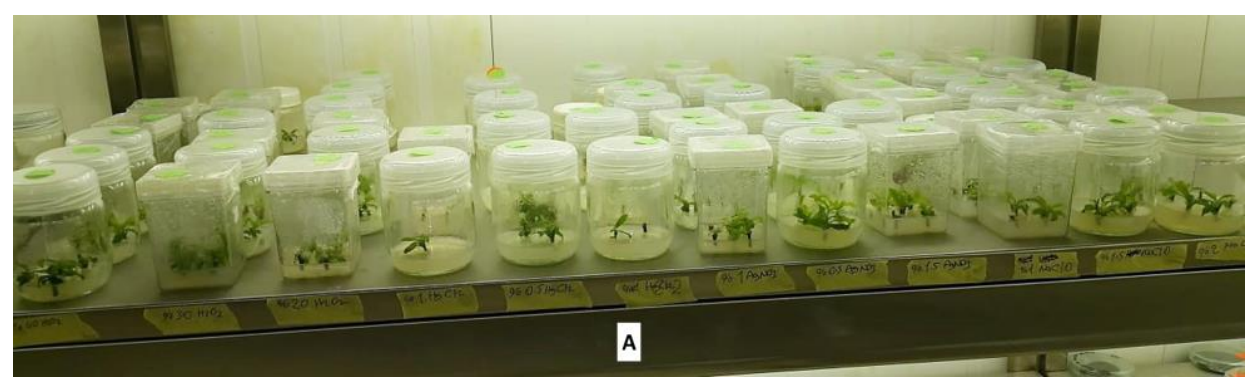

Figure 2. An image from the climate chamber, where the explants, whose sterilization procedures have been completed, are incubated

Data of percentage of survived explant, proliferation and shoot length, average number of leaf were analyzed by analysis of variance (ANOVA) in a completely randomized experimental design by SAS computer software (version 7.1). Significant different between means were assessed by Low Significant Different test (LSD, $\mathrm{P} \leq 0.05$ )

\section{Result and Discussion}

Table 2 shows the percentage of aseptic explant percentage at the end of applications on DO-1 ( $P$. domestica) rootstock taken under in vitro culture through application of different doses and durations of four different chemical agents. The variations arising from the effects of different chemicals on surface sterilization may also be seen on Table 2.

Table 2. Aseptic explant amount at the end of application different chemical agents (\%)

\begin{tabular}{|c|c|c|c|c|c|}
\hline \multirow[b]{2}{*}{ Treatments } & \multirow{2}{*}{$\begin{array}{l}\text { Chemical } \\
\text { agents }\end{array}$} & \multicolumn{2}{|c|}{ Application Combinations } & \multirow{2}{*}{$\begin{array}{c}\text { Application Mean } \\
(\%)\end{array}$} & \multirow{2}{*}{$\begin{array}{l}\text { Chemical } \\
\text { Mean }(\%)\end{array}$} \\
\hline & & $\begin{array}{c}\text { Concentrations } \\
\left(\% \mathbf{w v}^{-1}\right)\end{array}$ & $\begin{array}{c}\text { Durations } \\
\text { (minute) }\end{array}$ & & \\
\hline $\mathrm{T} 1$ & $\mathrm{HgCl}_{2}$ & 0.1 & 15 & $26.66^{\mathrm{d}}$ & \multirow{3}{*}{$27.77^{\mathrm{c}}$} \\
\hline $\mathrm{T} 2$ & $\mathrm{HgCl}_{2}$ & 0.5 & 10 & $23.33^{\mathrm{d}}$ & \\
\hline $\mathrm{T} 3$ & $\mathrm{HgCl}_{2}$ & 1.0 & 5 & $33.33^{\mathrm{d}}$ & \\
\hline $\mathrm{T} 4$ & $\mathrm{NaClO}$ & 1.0 & 30 & $88.66^{\mathrm{a}}$ & \multirow{3}{*}{$81.66^{\mathrm{a}}$} \\
\hline T5 & $\mathrm{NaClO}$ & 1.5 & 20 & $65.33^{\mathrm{bc}}$ & \\
\hline T6 & $\mathrm{NaClO}$ & 2.0 & 15 & $91.00^{\mathrm{a}}$ & \\
\hline $\mathrm{T} 7$ & $\mathrm{H}_{2} \mathrm{O}_{2}$ & 20.0 & 30 & $70.00^{\mathrm{bc}}$ & \multirow{3}{*}{$67.77^{b}$} \\
\hline $\mathrm{T} 8$ & $\mathrm{H}_{2} \mathrm{O}_{2}$ & 30.0 & 20 & $60.00^{\mathrm{bc}}$ & \\
\hline T9 & $\mathrm{H}_{2} \mathrm{O}_{2}$ & 40.0 & 10 & $73.33^{\mathrm{b}}$ & \\
\hline T10 & $\mathrm{AgNO}_{3}$ & 0.5 & 30 & $61.33^{\mathrm{bc}}$ & \multirow{3}{*}{$60.44^{\mathrm{b}}$} \\
\hline $\mathrm{T} 11$ & $\mathrm{AgNO}_{3}$ & 1.0 & 20 & $64.33^{\mathrm{bc}}$ & \\
\hline $\mathrm{T} 12$ & $\mathrm{AgNO}_{3}$ & 1.5 & 10 & $55.66^{c}$ & \\
\hline \multicolumn{4}{|c|}{ LSD chemical: $8.69^{* *}$} & \multicolumn{2}{|l|}{ LSD application: $7.51^{*}$} \\
\hline
\end{tabular}

$\mathrm{F}^{* *}$ indicate $\mathrm{P} \leq 0.01$ and $\mathrm{F}^{*}$ indicate $\mathrm{P} \leq 0.05$ significance level. Distinct letters in the fifth and sixth columns indicate significant differences according to LSD's test $(\mathrm{P} \leq 0.05)$

As a result, the differences among the aseptic explants obtained from application of the chemical agents) were observed to be significant at a level of $1 \%$. It was observed that the highest aseptic explant rate was $81.66 \%$ for $\mathrm{NaClO}$ (sodium hypochlorite) and followed by $\mathrm{H}_{2} \mathrm{O}_{2}$ (Hydrogen peroxide) and $\mathrm{AgNO}_{3}$ (silver nitrate) as $67.77 \%$ and $60.44 \%$, 
respectively. The lowest aseptic explant rate was obtained from $\mathrm{HgCl}_{2}$ (Mercury chloride) application as $27.77 \%$. Unlike to our study, Thakur et al. (2016) indicated that $\mathrm{HgCl}$ was a better disinfectant than $\mathrm{NaClO}$ during the surface sterilization stage of in vitro propagation of the explants (axillary buds) taken from Gisela-5 rootstock. However, it was observed in many studies that Ethanol, $\mathrm{NaClO}$ and Tween 20 prevent growth of bacteria and fungus when they are used as disinfectant in vitro culture. Even very little amounts of sodium hypochlorite ensure significant decrease in microbial population and it is rather effective disinfectant known as bacteria killer (Odutayo et al., 2007; Eed et al., 2010).

It was observed that the differences between the aseptic explant rates at interactions of application with different chemical agents for different durations were statistically important. The highest aseptic explant rates were obtained from application of $2 \% \mathrm{NaClO}$ for a duration of 15 minutes with $91.00 \%$ and 30 minutes $88.66 \%$; and the lowest explant rates were obtained from application of $0.5 \% \mathrm{HgCl}_{2}$ for a duration of 10 minutes and application of $0.1 \% \mathrm{HgCl}_{2}$ for a duration of 10 minutes with $23.32 \%$ and 15 minutes with $26.66 \%$, respectively.

When distribution of application combination interactions with chemical agents evaluated, the highest aseptic explant rates of the plants displayed a distribution between 60 and $70 \%$ while mercuric (II) chloride applications remained at very low levels (23 to $33 \%)$. Mihaljević et al. (2013) used different sterilization agents $\left(\mathrm{NaClO}, \mathrm{Ca}(\mathrm{ClO})_{2}\right.$, DICA, $\mathrm{HgCl}_{2}, \mathrm{AgNO}_{3}, \mathrm{H}_{2} \mathrm{O}_{2}$ ) for surface sterilization on the axillary buds of sour cherry plant in in vitro propagation. The best result was indicated to be achieved from application of $1 \% \mathrm{AgNO}_{3}$ for a duration of 20 minutes $(96.67 \%$ healthy and $3.3 \%$ contaminated bud explants). Similar to our study, the second best surviving explants obtained from 1-3\% $\mathrm{NaClO}$ application for surface sterilization with $80 \%$.

Table 3 shows the shoot growth [shoot length $(\mathrm{mm})$ ] data for the explants in vitro incubation after a duration of about 1 month in order to monitor the effect of four different surface sterilization agent on regeneration of the aseptic explants came from DO-1 $(P$. domestica) rootstock following in vitro culture.

Table 3. Shoot lengths of aseptic explants after application different chemical agents (mm)

\begin{tabular}{|c|c|c|c|c|c|}
\hline \multirow[b]{2}{*}{ Treatments } & \multirow[b]{2}{*}{ Chemical agents } & \multicolumn{2}{|c|}{ Application Combinations } & \multirow{2}{*}{$\begin{array}{c}\text { Application } \\
\text { Mean } \\
\text { (mm) }\end{array}$} & \multirow[b]{2}{*}{$\begin{array}{c}\text { Chemical Mean } \\
(\mathrm{mm})\end{array}$} \\
\hline & & $\begin{array}{c}\text { Concentrations } \\
\left(\% \mathbf{w v}^{-1}\right)\end{array}$ & $\begin{array}{c}\text { Durations } \\
\text { (minute) }\end{array}$ & & \\
\hline $\mathrm{T} 1$ & $\mathrm{HgCl}_{2}$ & 0.1 & 15 & $7.60^{\mathrm{bc}}$ & \multirow{3}{*}{8.31} \\
\hline $\mathrm{T} 2$ & $\mathrm{HgCl}_{2}$ & 0.5 & 10 & $8.00^{\mathrm{bc}}$ & \\
\hline $\mathrm{T} 3$ & $\mathrm{HgCl}_{2}$ & 1.0 & 5 & $9.33^{\mathrm{abc}}$ & \\
\hline $\mathrm{T} 4$ & $\mathrm{NaClO}$ & 1.0 & 30 & $9.23^{\mathrm{abc}}$ & \multirow{3}{*}{8.65} \\
\hline $\mathrm{T} 5$ & $\mathrm{NaClO}$ & 1.5 & 20 & $6.56^{\mathrm{c}}$ & \\
\hline T6 & $\mathrm{NaClO}$ & 2.0 & 15 & $10.16^{\mathrm{ab}}$ & \\
\hline $\mathrm{T} 7$ & $\mathrm{H}_{2} \mathrm{O}_{2}$ & 20.0 & 30 & $10.23^{\mathrm{ab}}$ & \multirow{3}{*}{9.86} \\
\hline $\mathrm{T} 8$ & $\mathrm{H}_{2} \mathrm{O}_{2}$ & 30.0 & 20 & $8.50^{\mathrm{abc}}$ & \\
\hline T9 & $\mathrm{H}_{2} \mathrm{O}_{2}$ & 40.0 & 10 & $10.86^{\mathrm{a}}$ & \\
\hline T10 & $\mathrm{AgNO}_{3}$ & 0.5 & 30 & $6.66^{\mathrm{c}}$ & \multirow{3}{*}{9.34} \\
\hline $\mathrm{T} 11$ & $\mathrm{AgNO}_{3}$ & 1.0 & 20 & $11.16^{\mathrm{a}}$ & \\
\hline $\mathrm{T} 12$ & $\mathrm{AgNO}_{3}$ & 1.5 & 10 & $10.20^{\mathrm{ab}}$ & \\
\hline \multicolumn{6}{|c|}{ LSD chemical: NS } \\
\hline
\end{tabular}

$\mathrm{F}^{* *}$ indicate $\mathrm{P} \leq 0.01$ and $\mathrm{F}^{*}$ indicate $\mathrm{P} \leq 0.05$ significance level. Distinct letters in the fifth and sixth columns indicate significant differences according to LSD's test $(\mathrm{P} \leq 0.05)$

It was observed that the differences among the shoot lengths of the sterile explants according to the applied chemical were not statistically important. According to Table 3, 
the highest shoot value was obtained for the explants, which were applied $\mathrm{H}_{2} \mathrm{O}_{2}$ $(9.86 \mathrm{~mm})$; and followed by $\mathrm{AgNO}_{3}, \mathrm{NaClO} \mathrm{HgCl}_{2}$, and applications with $9.34 \mathrm{~mm}$, $8.65 \mathrm{~mm}$ and $8.31 \mathrm{~mm}$, respectively. The results indicate that the lowest shoot length was obtained from $\mathrm{HgCl}_{2}$ application with $8.31 \mathrm{~mm}$.

The highest shoot length value was observed for application of $1 \% \mathrm{AgNO}_{3}$ for a duration of 20 minutes $(11.16 \mathrm{~mm})$ and for application of $2 \% \mathrm{H}_{2} \mathrm{O}_{2}$ for a duration of 15 minutes $(10.86 \mathrm{~mm})$ and that such interactions occurred in a way to take place in the same group statistically. The lowest shoot length values were observed as $6.56 \mathrm{~mm}$ for interaction of application of $1.5 \% \mathrm{NaClO}$ for a duration of 20 minutes and as $7.60 \mathrm{~mm}$ for application of $0.1 \% \mathrm{HgCl}_{2}$ for a duration of 15 minutes.

Table 4 shows the number of leaves developed on the shoots after application of shoot surface sterilization with four different sterilization chemicals on DO-1 ( $P$. domestica) rootstock. It was observed that the differences among the values of the numbers of leaves were not statistically different. As it may also be seen on the table, the highest number of leaves was obtained from $\mathrm{H}_{2} \mathrm{O}_{2}$ application as 6.54 leaves; followed by $\mathrm{NaClO}, \mathrm{AgNO}_{3}$ and $\mathrm{HgCl}_{2}$ applications as 6.35, 5.92 and 5.30 leaves, respectively.

Table 4. Average leaf numbers of the explants survived after application different chemical agents (per/explant)

\begin{tabular}{|c|c|c|c|c|c|}
\hline \multirow[b]{2}{*}{ Treatments } & \multirow[b]{2}{*}{ Chemical agents } & \multicolumn{2}{|c|}{ Application combinations } & \multirow{2}{*}{$\begin{array}{l}\text { Application } \\
\text { mean }\end{array}$} & \multirow[b]{2}{*}{ Chemical mean } \\
\hline & & $\begin{array}{c}\text { Concentrations } \\
\left(\% \mathbf{w v}^{-1}\right)\end{array}$ & $\begin{array}{c}\text { Durations } \\
\text { (minute) }\end{array}$ & & \\
\hline $\mathrm{T} 1$ & $\mathrm{HgCl}_{2}$ & 0.1 & 15 & 4.56 & \multirow{3}{*}{5.30} \\
\hline $\mathrm{T} 2$ & $\mathrm{HgCl}_{2}$ & 0.5 & 10 & 5.33 & \\
\hline $\mathrm{T} 3$ & $\mathrm{HgCl}_{2}$ & 1.0 & 5 & 6.00 & \\
\hline T4 & $\mathrm{NaClO}$ & 1.0 & 30 & 6.93 & \multirow{3}{*}{6.35} \\
\hline T5 & $\mathrm{NaClO}$ & 1.5 & 20 & 6.30 & \\
\hline T6 & $\mathrm{NaClO}$ & 2.0 & 15 & 5.83 & \\
\hline $\mathrm{T} 7$ & $\mathrm{H}_{2} \mathrm{O}_{2}$ & 20.0 & 30 & 6.23 & \multirow{3}{*}{6.54} \\
\hline T8 & $\mathrm{H}_{2} \mathrm{O}_{2}$ & 30.0 & 20 & 6.66 & \\
\hline T9 & $\mathrm{H}_{2} \mathrm{O}_{2}$ & 40.0 & 10 & 6.73 & \\
\hline T10 & $\mathrm{AgNO}_{3}$ & 0.5 & 30 & 4.46 & \multirow{3}{*}{5.92} \\
\hline $\mathrm{T} 11$ & $\mathrm{AgNO}_{3}$ & 1.0 & 20 & 6.86 & \\
\hline $\mathrm{T} 12$ & $\mathrm{AgNO}_{3}$ & 1.5 & 10 & 6.43 & \\
\hline \multicolumn{4}{|c|}{ LSD $_{\text {chemical: }}$ NS } & \multicolumn{2}{|c|}{ LSD application: NS } \\
\hline
\end{tabular}

$\mathrm{F}^{* *}$ indicate $\mathrm{P} \leq 0.01$ and $\mathrm{F}^{*}$ indicate $\mathrm{P} \leq 0.05$ significance level. Distinct letters in the fifth and sixth columns indicate significant differences according to LSD's test $(\mathrm{P} \leq 0.05)$

The highest number of leaves was observed at interaction of $1 \% \mathrm{NaClO}$ application for a duration of 30 minutes as 6.93 leaves and $1 \% \mathrm{AgNO}_{3}$ application for a duration of 20 minutes as 6.86 leaves. On the other hand, the lowest number of leaves was observed on the aseptic explants obtained at the interaction of $0.5 \% \mathrm{AgNO}_{3}$ application for a duration of 30 minutes as 4.46 leaves and $0.1 \% \mathrm{HgCl}_{2}$ application for a duration of 15 minutes as 4.56 leaves.

It was reported that the explants obtained from the buds of the shoots, which have completed their development, gave better results (Naghmouchi et al., 2008). Our study showed that when the explants were taken from in vitro culture, the season was important for the success of the surface sterilization. And especially spring season affected in vitro regeneration positively as the shoots taken in spring are active. It was reported that in vitro culturing time of the explants to be taken from woody plants (cherry rootstocks) was very 
important in terms of contaminations and that contamination was less especially in spring months and that development was faster (Fidanc1 et al., 2008).

Another factor affecting the shooting speed of the explants of DO-1 (P. domestica) rootstocks (exposed to different chemical agents) is whether the caustic effect of the chemical agent is high or not as well as the duration of keeping the explants in such chemicals. It was observed that the explants (67.77\% aseptic) exposed to $\mathrm{H}_{2} \mathrm{O}_{2}$ application are distinguished for their shoot lengths and leaf numbers. And also the caustic effect of $\mathrm{NaClO}$ chemical, which gave the highest value of $81.66 \%$ in terms of aseptic plants, was higher and hence lower values were obtained in regeneration of the shoots.

\section{Conclusion}

Surface sterilization is first stage of in vitro culture and it is important for healthy and fast growth. In order to achieve this, the proper chemical agent for surface sterilization and the application duration of the chemical agent have to be determined according to some criteria; such as explant taking time of the species and varieties to be taken into in vitro culture, the texture of the explants (indented, puberulent, spinous, waxy, etc.) and types of the explants (leaf, stem, bud, etc.) (Mihaljevic et al., 2013; Nongalleima et al., 2014). The method, which would avoid contamination and give the least damage to the explant, has to be determined in order to avoid loss of time for the rootstocks that has to be produced in vitro mass micropropagation. It is necessary to achieve maximum level of regeneration speed of the explants to be source in the future.

In this study, a protocol for surface sterilization of clonal rootstock DO-1 ( $P$. domestica) was developed using axillary bud explant. During sterilization protocol investigation, the highest significant survival value $(91 \%)$ was recorded when disinfected with T6 (2\% $\mathrm{NaClO}$ for $15 \mathrm{~min}$ ). The induction, regeneration and proliferation of this explants were depending on the application combination and duration times of chemical agents that were used. The length of newly shoot varied with application chemical agents and duration times. The best length of shoot was obtained on $\mathrm{T} 11\left(1 \% \mathrm{AgNO}_{3}\right.$ for $\left.20 \mathrm{~min}\right)$ treatments. Whereas no differences were found between the number of leaf values of explants. Therefore, treatments of $\mathrm{T} 6(2 \% \mathrm{NaClO}$ for $15 \mathrm{~min})$ is recommended for true type and disease free plants of DO-1 (P. domestica).

The results of the study showed that $\mathrm{HgCl}_{2}$, which has an extremely toxic effect, gave negative results in surface sterilization of plant explant in our in vitro studies. Although the best surface sterilization results were obtained with $\mathrm{NaClO}$, the use of $\mathrm{H}_{2} \mathrm{O}_{2}$ and $\mathrm{AgNO}_{3}$ also yielded positive results (Figure 3).
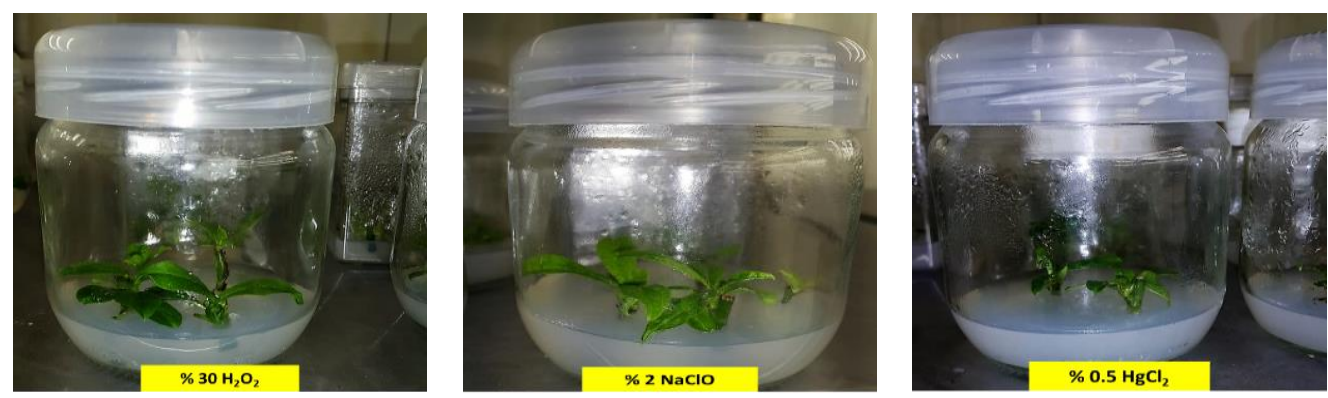

Figure 3. Development of the aseptic plants at the incubation medium after application of different chemical agents at surface sterilization 


\section{REFERENCES}

[1] Ainsley, J., Hammerschlag, A. F., Bertozzi, T., Graham, G. C., Sedgley, M. (2001): Regeneration of almond from immature seed cotyledons. - Plant Cell, Tissue and Organ Culture 67: 221-226.

[2] Altan, F., Bürün, B., Sahin, N. (2010): Fungal contaminants observed during micropropagation of Lilium candidum L. and the effect of chemotherapeutic substances applied after sterilization. - African Journal Biotechnology 9: 991-995.

[3] Andreu, P., Marin, J. A. (2005): In vitro culture establishment and multiplication of the Prunus rootstock 'Adesoto 101' ( $P$. insititia L.) as affected by the type of propagation of the donor plant and by the culture medium composition. - Scientia Horticulturae 106: 258262.

[4] Arab, M. M., Yadollahi, A., Mazinani-Hossaini, M., Bagheri, S. (2014): Effects of antimicrobial activity of silver nanoparticles on in vitro establishment of G N15 (hybrid of almond X peach) rootstock. - Journal of Engineering and Biotechnology 12: 103-110.

[5] Babaoglu, M., Yorgancilar, M., Akbudak, M. A. (2002): Doku Kültürü: Basic Laboratory Techniques. - Selcuk University Foundation Publications, Konya.

[6] Beckman, T. G., Lang, G. A. (2003): Rootstock Breeding for Stone Fruits. XXVI IHC Genetics and Breeding of Tree Fruits and Nuts. - Acta Horticulture 622: 531-551.

[7] Bhansali, R. R., Driver, J. A., Durzan, D. J. (1990): Rapid multiplication of adventitious somatic embryos in peach and secondary embryogenesis. - Plant Cell Report 9: 280-284.

[8] Bhojwani, S. S., Razdan, M. K. (2005): Plant Tissue Culture: Theory and Practice. Elsevier, New Delhi, India: 30-35.

[9] Canli, F. A., Demir, F. (2014): In vitro multiplication and rooting of 'F12-1' (Prunus avium L.) and 'Ma X ma 14' (Prunus mahaleb L. $\times$ P. avium L.) rootstocks. - Indian Journal of Horticulture 71: 145-150.

[10] Choudhary, R., Chaudhury, R., Malik, S., Sharma, K. (2015): An efficient regeneration and rapid micropropagation protocol for Almond using dormant axillary buds as explants. Indian Journal Experimental Biology 53: 462-467.

[11] Da Silva, J. A. T., Kulus, D. (2014): Chrysanthemum biotechnology: discoveries from the recent literature. - Folia Horticulture 26: 67-77.

[12] Da Silva, J. A. T., Kulus, D., Zhang, X., Zeng, S., Ma, G., Piqueras, A. (2016): Disinfection of explants for saffron (Crocus sativus) tissue culture. - Environmental Experimental Biology 14: 183-198.

[13] Declerck, V., Korban, S. S. (1996): Influence of growth regulators and carbon source on callus induction, growth and morphogenesis from leaf tissues of peach (Prunus persica $\mathrm{L}$. Batsch). - Journal Horticultural Science 71(1): 49-55.

[14] Dejampour, J., Majidi, I., Khosravi, S., Farhadi, S., Shadmehr, A. (2011): In Vitro Propagation of HS314 Rootstock (Prunus amygdalus $x$ P. persica). - HortScience 46(6): 928-931.

[15] Eed, A. M., Reddy, A. S., Reddy, K. M., Silva, J. A. T., Reddy, V. P., Beghum, H., Venkatsubbaiah, P. Y. (2010): Effects of Antibiotic and Fungucides on the in vitro Production of Citrus limonia Osbeck Nodal Segment and Shoot Type Explants. - Asian and Australasian Journal of Plant Science and Biotechnology 4(1): 66-70.

[16] FAO. (2019): Food and Agricultural Organization. 20 June 2019. http://www.fao.org/faostat/en/\#data/QC.

[17] Felek, W., Mekibib, F., Admassu, B. (2015): Optimization of explant surface sterilization condition for field grown peach (Prunus persica L. Batsch Cv. Garnem) intended for in vitro culture. - African Journal of Biotechnology 14(8): 654-660.

[18] Felipe, A. J. (2009): 'Felinem', 'Garnem' and 'Monegro' almond x peach hybrid rootstocks. - HortScience 44(1): 196-197. 
[19] Fidanci, A., Burak, M., Erenoglu, B., Akcay, M. E. (2008): Determination of in vitro propagation techniques for some clonal cherry rootstocks. - Acta Horticulture 795: 409412.

[20] Hesami, M., Naderi, R., Yoosefzadeh-Najafabadi, M. (2018): Optimizing sterilization conditions and growth regulator effects on in vitro shoot regeneration through direct organogenesis in Chenopodium quinoa. - BioTechnologia 99: 49-57.

[21] Martinez-Gomez, P., Sanchez-Perez, R., Rubio, M., Dicenta, F., Gradziel, T. M., Sozzi, G. O. (2005): Application of recent biotechnologies to Prunus tree crop genetic improvement. - Ciencia e Investigación Agraria 32(2): 55-126.

[22] Matt, A., Jehle, J. A. (2005): In vitro plant regeneration from leaves and internode sections of sweet cherry cultivars (Prunus avium L.). - Plant Cell Reports 24: 468-476.

[23] Mihaljević, I., Dugalić, K., Tomaš, V., Viljevac, M., Pranjić, A., Čmelik, Z., Puškar, B., Jurković, Z. (2013): In vitro sterilization procedures for micropropagation of 'OBLAČINSKA' Sour Cherry. - Journal of Agricultural Sciences 58: 117-126.

[24] Murashige, T., Skoog, F. (1962): A revised medium for rapid growth and bioassays with tobacco tissue cultures. - Physiology of Plant 15: 473-497.

[25] Naghmouchi, S., Khouja, M. L., Rejep, M. N., Boussaid, M. (2008): Effect or growth regulators and eksplant origin on in vitro propagation of Ceratonia siliqua L. Via cuttings. - Biotechnologie Agronomie Societe Environment 12(3): 251-258.

[26] Nazary, R., Aghaye, M. (2012): Micropropagation of GF 677 Rootstock. - Journal Agricultural Science 4(5): 131-138.

[27] Nimbolkar, P. K., Shiva, B., Rai, A. K. (2016): Rootstock breeding for abiotic stress tolerance in fruit crops. - International Journal of Agriculture, Environment and Biotechnology 9(3): 375-380.

[28] Nongalleima, K., Dikash Singh, T., Amitabha, D., Deb, L., Sunitibala Devi, H. (2014): Optimization of surface sterilization protocol, induction of axillary shoots regeneration in Zingiber zerumbet (L.) Sm. as affected by season. - Biological Rhythm Reserach 45: 317 324.

[29] Odutayo, O. I., Amusa, N. A., Okutade, O. O., Ogunsanwo, Y. R. (2007): Sources of microbial contamination in tissue culture laboratories in southwestern Nigeria. - African Journal Agricultura 2: 067-072.

[30] Omamor, I. B., Amusa, N. A., Eke, C. R., Ezia, E. L. (2007): Fungal contamination of the oil palm tissue culture in Nigerian institute for Oil Palm Research (NIFOR). - African Journal Agriculture 2(10): 534-537.

[31] Papafotiu, M., Martini, A. N. (2009): Effects of season and sterilization method on response of Malasorbus florentina Browies (Rosacea) buds in vitro culture. - Acta Horticulturae 813: 503-508.

[32] Perez-Tornero, D., Egea, J., Van Oostende, A., Burgos, L. (1999): Assessment of factors affecting adventitious regeneration from in vitro cultured leaves of apricot. - Plant Science 158: 61-70.

[33] Reighard, G. L., Cain, D. W., Newall Jr., W. C. (1990): Rooting and survival potential of hardwood cuttings of 406 species, cultivars, and hybrids of Prunus. - HortScience 25(5): 517-518.

[34] Ružić, D. V., Vujović, T. (2008): The effects of cytokinin types and their concentration on in vitro multiplication of sweet cherry cv. Lapins (Prunus avium L.). - Horticultural Science 35: 12-21.

[35] Suranyi, D. (2019): Evaluation of introduced plum varieties under extreme climatic conditions. - International Journal of Horticultural Science 25(1-2): 7-10.

[36] Tsipouridis, C., Thomidis, T. (2003): Methods to improve the in vitro culture of GF677 (peach $\times$ almond) peach rootstock. - New Zealand Journal of Crop and Horticultural Science 31: 361-364.

[37] Wolella, E. K. (2017): Surface sterilization and in vitro propagation of Prunus domestica L. cv. Stanley using axillary buds as explants. - Journal of Biotech Research 8: 18-26. 
[38] Zarei, M., Garoosi, G., Nezami, E., Hosseini, R., Ahmadi, J. (2013): The effect of medium, carbon source, light spectrum and style treatment of auxin on shoot and root regeneration of 'Gisela 6' rootstock. - Journal of Cell \& Tissue Culture 4: 169-185. 